\title{
Neurological examination: pioneering authors and their books
}

\author{
Exame neurológico: autores pioneiros e seus livros \\ Péricles Maranhão-Filho ${ }^{1,2}$, Maurice Borges Vincent ${ }^{1}$, Marcos Martins da Silva ${ }^{1}$
}

\begin{abstract}
The objective of this article is to highlight some of the most important pioneering books specifically focused on the neurological examination and their authors. During the XIX Century, Alexander Hammond, William Gowers and Charles Mills pioneered the neurological literature, followed in the XX Century by Aloysio de Castro, Monrad-Krohn, Derek Denny-Brown, Robert Wartenberg, Gordon Holmes, and Russel DeJong. With determination and a marked sense of observation and research, they competently developed and spread the technique and art of the neurological exam.
\end{abstract}

Keywords: neurologic examination, textbooks, semiology.

RESUMO

O objetivo deste artigo é destacar alguns dos primeiros e mais importantes livros-texto interessados em difundir o ensino do exame neurológico e seus autores. Durante o século XIX, Alexander Hammond, William Gowers e Charles Mills foram pioneiros na literatura neurológica, seguidos por Aloysio de Castro, Monrad-Krohn, Derek Denny-Brown, Robert Wartenberg, Gordon Holmes e Russel DeJong no século XX. Com determinação, grande senso de observação e pesquisa, eles competentemente disseminaram a técnica e a arte de se realizar o exame neurológico.

Palavras-chave: exame neurológico, livros-texto, semiologia.

Although the case history generally remains as the main source of data for a proper diagnosis, the neurological examination (NE) as we know today is a critical element in clinical practice. The NE is based on a systematic sequence of maneuvers specifically conceived to highlight dysfunctions in various parts of the nervous system. The XIX and the beginning of the XX Centuries were particularly fruitful for the settlement of the NE, when seminal textbooks on the subject were published. We herein highlight some of these pioneer books and comment on their authors.

J. M. Charcot (1825-1893), the father of modern neurology ${ }^{1}$, applied the clinical-pathological method by correlating signs and symptoms to morbid anatomy, but there is sparse literature about how he would perform the NE. The lack of documentation is probably related to the fact that the $\mathrm{NE}$ was not systematized at the time $^{2}$ and rather based on observational analysis of selected phenomena. ${ }^{3}$. The NE developed significantly after him as the following generation of physicians incorporated his findings and progressively developed a systematic approach.

The written neurologic teaching emerged during the XIX Century. Four books, three published in London and one in Germany, were seminal in the initial development of neurology: "A Treatise on the Nervous Diseases" by John Cooke in 1820, "The Nervous System of the Human Body" by Charles Bell in 1830, "Lectures on the Nervous System and its Diseases" by Marshall Hall in $1836^{4,5}$ and Lehrbook der Nervenkrankheiten des Menschen ("A Manual of Nervous Diseases of Man”) by Moritz Romberg in 1840. Romberg's work was the first neurology textbook to be considered profoundly influential, not only in Germany but also in United Kingdom, after its translation, in 1853, by E. H. Sieveking, one of the first physicians at Queen Square. Two Americans, Alexander Hammond and Charles Mills, and a British author, William Gowers, should also be honored as pioneers in publishing neurology books.

\footnotetext{
${ }^{1}$ Universidade Federal do Rio de Janeiro, Faculdade de Medicina, Hospital Universitário Clementino Fraga Filho, Departamento de Clínica Médica, Rio de Janeiro RJ, Brazil;

${ }^{2}$ Instituto Nacional de Câncer do Rio de Janeiro, Hospital do Câncer, Rio de Janeiro RJ, Brazil.

Correspondence: Péricles Maranhão-Filho; Av. Prefeito Dulcídio Cardoso, 1680/1802; 22620-311 Rio de Janeiro RJ, Brasil;

E-mail:pmaranhaofilho@gmail.com

Conflict of interest: There is no conflict of interest to declare.

Received 07 January 2014; Received in final form 07 October 2014; Accepted 27 October 2014.
} 
William Alexander Hammond (1828-1900), a general surgeon at the United States Army, was the first American to devote himself full-time to neurology. Hammond was described as, "a dominant personality in any field he entered, attracting a following and developing active enemies"7, 8 . His theatrical behavior, large build and powerful speaking ability attracted much attention. Originally from Maryland, he moved with his parents to Pennsylvania at age of five, where he lived until starting medical school. He received his MD from the University of the City of New York at the age of twenty. In 1849, he entered the U.S. Army as an assistant surgeon where he worked for eleven years. He participated in several campaigns against Indians in New Mexico and Kansas. In 1860, Hammond resigned his military post to become in charge of the anatomy and physiology departments at the University of Maryland's medical school. However, he would rejoin the army in 1861 to participate in the civil war. After the war, his career remained active and he became a professor of nervous and mental diseases at several medical schools. Neurology was a new specialty, and Hammond became a pioneer in the field ${ }^{8}$.

Mainly based on his observations, clinical investigations, and Charcot texts, he published his "Treatise on Diseases of the Nervous System" in 1872. A sixth edition was published in $1876^{9}$ (Figure 1). With 750 pages divided into 42 chapters, Hammond created the first concise and explicit neurological textbook in the English language. He introduced his treatise with a thorough description of instruments used for the diagnosis and treatment of neurological diseases and aspects of the NE directly related to these tools. At a cost of $\$ 4.00$, Hammond's textbook was enthusiastically received by most of his peers, but unfortunately he did not discuss the neurological examination in a systematic way ${ }^{4}$.

Sir William Richard Gowers (1845-1915), was born in Hackney, England, now a suburb of London, in his father's cobbler shop. Gowers lived in dire poverty as a child due to the death of his father when he was $11^{10}$. He was awarded the MD degree with a Gold Medal from the University of London in 1870 and spent nearly his entire career at the National Hospital for the Paralyzed and Epileptic in Queen Square, London. Gowers not only helped define the modern

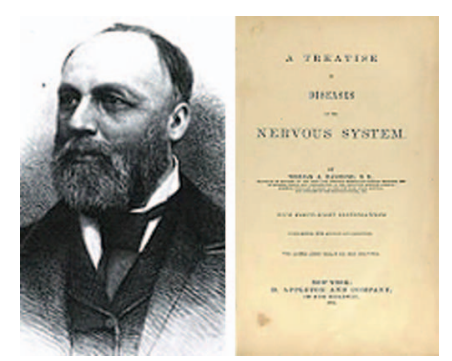

Figure 1. William Alexander Hammond and the first page of his 1872 book. neurological examination, but also made epochal contributions to our knowledge of many diseases ${ }^{11}$. In 1888 Gowers simultaneously published American and English editions of "A Manual of Diseases of the Nervous System"12 (Figure 2 ), containing descriptions of neurological diseases as well as methods to examine muscular strength, coordination, sensory perception, tone, tremor, reflexes, actions of individual muscles, and cranial nerves. His book was published in two volumes - the first, dedicated to the study of spinal cord diseases, was immediately acclaimed as the "Bible of Neurology"13. Spillane (1891) suggested that it should be considered as the neurology "new testament"14. In this superb text regarding an extensive range of topics, Gowers used a highly descriptive prose and included definitive line drawings made by himself.

Charles Karsner Mills (1845-1931), was born at the Falls of the Schuylkill River, a suburb of Philadelphia. He graduated from the Central High School in 1861. After interrupting his education by volunteering to fight for the Union in the deadly Civil War battles at Bull Run and Gettysburg, he graduated from the University of Pennsylvania medical school in 1869. Mills was appointed Professor of Nervous and Mental Disease at the same University in 1893 and Professor of Neurology in $1901^{9}$. In 1898, just after he had published "The Nervous System and Its Diseases, a Practical Treatise on Neurology for the use of Physicians and Students"14 (Figure 3) - 1056 pages which became known as the last important American textbook on neurology of the XIX Century and the first formal and comprehensive review of the NE - Mills was struck by a bicyclist and had the retinae detached. Despite his poor vision, he had an extraordinary auditory memory that he used to recall almost verbatim the contents of journals and books that his friends read to him. Mills died of acute pulmonary edema on the day he was to present a paper at the American Neurological Association.

During the XX Century, six main authors disseminated and expanded the knowledge on the NE through carefully drafted textbooks (Table).

A Brazilian author deserve consideration. Born in Rio de Janeiro, Aloysio de Castro (1881-1959) was a physician, teacher, writer, literary critic, poet and musician. He joined

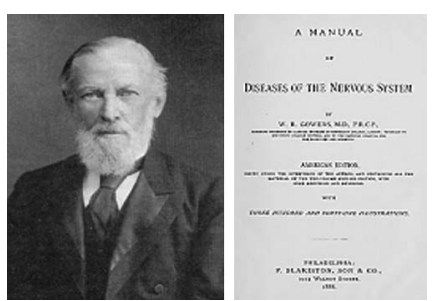

Figure 2. Sir William Richard Gowers and the first page of the second volume of the first edition of his 1888 book. 


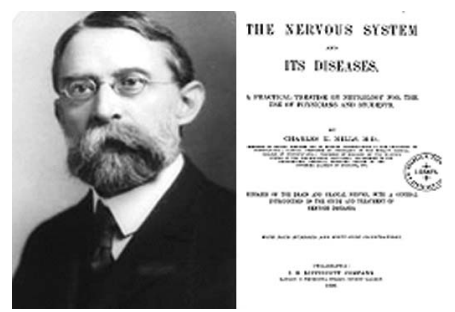

Figure 3. Charles K. Mills and the first page of his 1898 book.

the Faculdade de Medicina da Universidade Federal do Rio de Janeiro in 1898 and until the 4th year was a student of his father, Francisco Castro, also a physician and professor, known as the "Divine Master." Aloysio graduated at age $22^{15}$. His 232 pages graduation thesis entitled Das Desordens da Marcha e seu Valor Clínico (1904)" ("Gait Disorders and Their Clinical Value") (Figure 4), revealed his talent as a great scientist and exceptional writer, representing a real innovation in both form and content as compared to contemporary medical texts.

For emerging as the best student in his class and completing medical school with honors, the College of Medicine council awarded him a trip abroad in order to improve their knowledge. In May 1906 he arrived in Paris and was presented to Pierre Marie, at that time considered the best neurologist alive. His training took place mainly in Hôpital Bicêtre and involved neurology, pathology, and clinical practice ${ }^{17,18,19}$.

Upon his return to Brazil, de Castro worked in the Santa Casa de Misericórdia do Rio de Janeiro and as Chief of Internal Medicine at Policlínica Geral do Rio de Janeiro, where he created the first outpatient clinic where students could observe his work. He also innovated in the study and dissemination of medical education by filming patients. De Castro produced 130 movies of neurological diseases with a primary focus on gait and movement disorders ${ }^{18}$.

In 1914 he published the "Tractado de Semiotica Nervosa"19 (Figure 4), the first Brazilian book completely focused on NE. He thus introduced the local medical iconography using

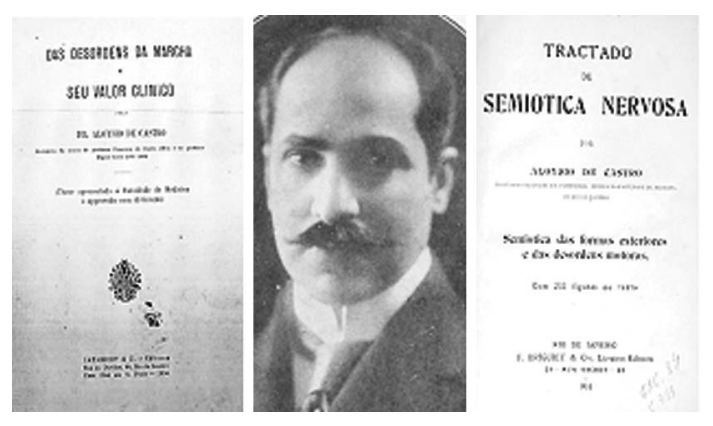

Figure 4. Aloysio de Castro, the first pages of his MD conclusion Thesis (1904) (left), and the 1st Edition of his book 1914 (right). photography (not drawings) and excerpts from movies. In the same year he was elected dean of the school of medicine. In 1935 he re-edited his book, revised and enlarged under the title "Semiotica Nervosa"20. Although Professor Aloysio de Castro dominates other languages including French and English, his thesis and the books were published only in Portuguese. Therefore, his work did not produce international impact it deserved.

Georg Herman Monrad-Krohn (1884-1964) was a Norwegian neurologist trained at the Queen Square Hospital in London. He wrote the first book on clinical examination of the nervous system in Norway, published in Oslo in 1914. The English-language edition - "The Clinical Examination of the Nervous System" - edited by H.K. Lewis \& Co, LTD., was released in London in $1921^{21}$.

The idea of the book was to present a comprehensive approach to the NE through a method based on examination of the functional status followed by anatomic and aetiological diagnosis. The book, known as the "Blue Bible" or "Blue Book of Neurology," as Norwegian students called it, was reprinted 12 times and translated into many languages. The translation of the eleventh edition ${ }^{22}$ (Figure 5), coauthored with Professor Sigvald Bernhard Refsum, who replaced Monrad-Krohn as Chair in the direction of Neurology University of Oslo, has 16 chapters spread over 500 pages containing dozens of interesting footnotes and an appendix in which he addresses various forms of specific clinical approaches such as aphasia, diplopia, vestibular tests, loss of consciousness, etc., and electric exams. The book concludes with discussion over simulator neurological examinations ${ }^{22}$. Refsum developed a reputation as talented lecturer able to improvise virtually any speech, a skill actually trained to exhaustion in a detailed way (Ottar Sjaastad, personal communication to MBV).

The Blue Bible offers a detailed description of a detailed NE and highlights important topics such as the dissociation of emotional mimicry in central facial paresis and cutaneous abdominal reflexes (while training in Queen Square Hospital, Monrad-Krohn completed a thesis on the abdominal reflex).
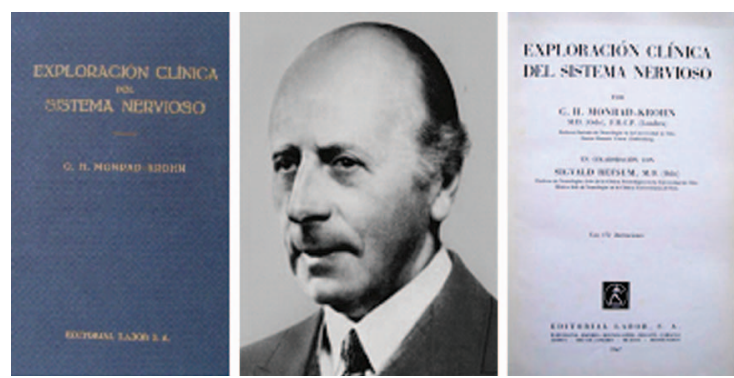

Figure 5. Monrad-Krohn, the "Blue bible". Front page (left), and the first page of this eleventh edition book translation 1967 (right). 
In addition, the author calls attention to an unusual response not previously cited in the static equilibrium test: "Some neurotic patients, mostly very thin women with a tendency to hypochondria, imbued by an absurd horror of losing their balance, generally fall during the current Romberg test towards the physician performing the test in order to lean on them for support (though sometimes for different reasons!)". Monrad-Krohn consider the examination of sensory perception as the hardest part of the NE and suggest a technique difficult to be applied today: “(...) to get a general idea at first glance, then conducting a closer examination on a second opportunity, for example, the next day when the patient is quiet (...)”.

Derek Ernest Denny-Brown (1901-1980) was born and went to medical school in New Zealand. During his medical school years from 1919 until 1924 he was particularly stimulated by anatomy and physiology. After graduation he received an appointment as Beit Memorial Fellow for Medical Research, which permitted him to spend three years in Sir Charles S. Sherrington laboratory's in Oxford, England ${ }^{25}$. In December 1928, Denny-Brown became a Resident Medical Officer at the National Hospital, Queen Square, London, where he completed his neurology training. Dr. Denny-Brown found himself amid a number of superb clinicians and teachers, including Kinnier Wilson, Gordon Holmes, Charles Symonds, James Collier, and Francis Walshe. He learned his approach to clinical neurology from many of these individuals, but particularly from Charles Symonds and Gordon Holmes $^{25}$. Next he moved to America and became director of the Neurological Unit at Boston City Hospital and James Jackson Putnam professor of neurology at Harvard. With the support and advice of Raymond Adams and Harry Kozol he published the "Handbook of Neurological Examination and Case Recording" in March 1942, a private printing for the Neurological Unit. This small wire-bound booklet went through three editions. The 1942 edition was reprinted in $1952^{26}$ (Figure 6). This extremely useful text, containing 11 chapters in 108 pages but less than 10 references, has been used widely throughout the United States and abroad as a beginner's guidebook to the neurologic examination. Seventy years ago, in Friday October 22, 1943, DennyBrown was in the Medical School Faculty Room, as a reader

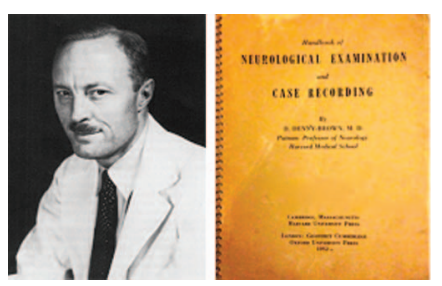

Figure 6. Derek Denny-Brown and the cover of his book, 1942 edition, reprint in 1952. of the PhD Thesis entitled "Spreading Depression of Activity in the Cerebral Cortex" by the Brazilian scientist Aristides Azevedo Pacheco Leão (personal communication from A.A. P. Leão to PM-F).

Denny-Brown was president of the American Neurological Association. In 1967, he retired from his position as director of the Neurological Unit at the Boston City Hospital and took up a post as chief in charge of the Section of Neurophysiology and associate director of the New England Regional Primate Center ${ }^{25}$. He studied the effects of sectioning dorsal roots in apes ${ }^{27}$ and continued his interest in dystonia, describing abnormal postures from lesions of the basal ganglia and cerebral cortex in infant primates. In 1972, he became a Fogarty Scholar in Residence at the National Institutes of Health for one year and then entered a phase of semi-retirement. Denny-Brown was profoundly influenced by Sir Charles Sherrington and Gordon Holmes $^{8}$. He died at the age of 79 from complications of multiple myeloma at his home in Cambridge, Massachusetts ${ }^{25}$.

Robert Wartenberg (1887-1956) was born in the Russian Empire and graduated in Germany. In 1933, he was head of the neurological clinic at Freiburg. Persecuted by the Nazis, he left Germany and settled in USA in 1953. Wartenberg was appointed clinical professor of neurology at the University of California, San Francisco ${ }^{21}$. He was considered an outstanding teacher, book reviewer/critic, and editor who despised mediocrity. In 1945 published "The Examination of Reflex: A Simplification” (reprinted in 1946) (Figure 7$)^{28}$. With an introduction by Foster Kennedy and the preface by Wartenberg himself, the book highlights the reflexes as being the most important part of the NE. The exquisite book has 222 pages, only seven figures, and 465 excellent references. After nearly 70 years from publication, no other book rivals its depth and clarity on this issue. In 1953 he released "Diagnostic Tests in Neurology: A Selection for Office Use", reprinted in April $1954^{29}$ (Figure 7). The “ diagnostic tests” list maneuvers that easily applied at bedside. The audience was said to be general practitioners, although Holmes clarified in

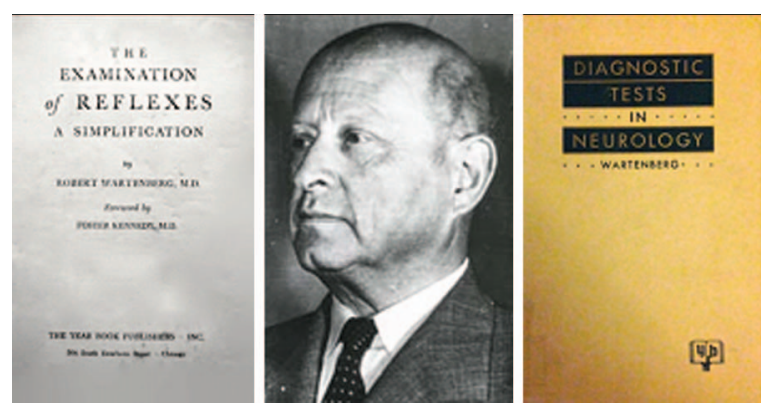

Figure 7. Robert Wartenberg. The front page of his Reflex Examination book 1945, reprinted 1946 (left), and the cover of his Diagnostic Test book, English 1953 edition, reprinted in U.S. A., 1954 (right). 
the foreword that the book would be useful for neurologists as well. In 228 pages, Wartenberg exalts the importance and subtlety of the various signals present in patients with neurological ailments, like the precocity and longevity of absent lid vibration in cases of peripheral facial palsy, the arm stretching in lesions of the spinal nerve, and the trick to palpate the tendons hypotonia in cases of peripheral nerve injury. He brilliantly explores the diagnostic possibilities in relation to the deep and superficial abdominal reflexes alterations. The book, containing two indexes - a general one and other special based on the morbid condition and its pertinent bedside tests - was translated into several languages, and went through three editions in German (one in English). Another example of his didactic and writing abilities may be found in the first issue of the Neurology journal (January 1951), where Wartenberg publishes the article "Pendulousness of the Legs as a Diagnostic Test" ${ }^{\text {"30 }}$, showing elegantly how to draw several conclusions concerning the pendulum movements from the simple act of lifting and dropping the leg in a sitting extrapyramidal rigidity patient.

Gordon Morgan Holmes (1876-1965), was born in a family line of protestant farmers at Castlebellingham, Louth County, Ireland ${ }^{9,23}$. He studied medicine in Dublin and graduated from the Trinity College in medicine at age 23. He then spent two years doing research with Edinger and Weigert in Frankfurt ${ }^{21}$. Holmes went to London in 1903 and completed his neurological training as Assistant House Physician at National Hospital, Queen Square, where he worked for Hughlings Jackson ${ }^{24}$. He eventually became Physician and Director of research at the National Hospital, consultant to the British Expeditionary Force in World War I, and editor of the journal Brain between 1922 and 1937. Holmes was remembered as a big man with black curly hair, dark black eyes and a thick moustache, and was known for his remarkable bedside teaching ability. Macdonald Critchley noted "He could coax physical signs out of a patient like Paganini on the violin"24.

With Grainger Stewart he described the rebound phenomenon in cerebellar diseases (Stewart-Holmes Symptom). With W. J. Adie he established the myotonic, or Holmes Adie, pupil. Holmes' Syndrome is a hereditary degenerative cerebellar ataxia involving the olivary nucleus ${ }^{23}$.

Gordon Holmes, more than any other individual, was responsible for the form of the NE as it is now performed; and his insights are fundamental to the way that, nowadays, we think about vision, somato-sensory function, the spinal cord and the cerebellum ${ }^{24,31,32}$.

Holmes distilled the essence of his teaching at the National Hospital in his classic 1946 book "Introduction to Clinical Neurology", laying down the foundations of the modern NE. The last of three editions, with 187 pages and 21 chapters $^{32}$, and revised by Bryan Matthews, was published in 1968 and reprinted in 1971 (Figure 8). The writing style is

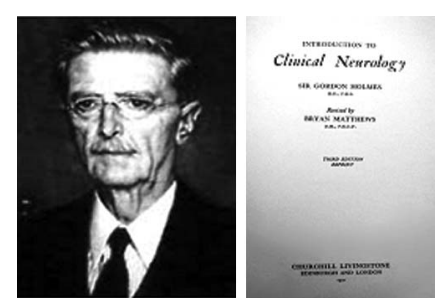

Figure 8. Sir Gordon Holmes and the first page of his book, third edition (1968), reprinted in 1971.

elegant and sober and the figures are simple diagrams. His account of the mental state exam is clear and succinct and provides a useful framework even by modern's standards. In a section on suggestibility (page 179), he says "even normal persons are suggestible; any one can walk along a plank lying on firm ground, but may be unable to do so when it spans an abyss". Two curiosities are queer in this book: First, there are no references; second, although there are five pages on the vestibular system in the Appendix, when he describes "a scheme for the clinical investigation of the function of the nervous system," there is no mention of the vestibulocochlear nerve examination.

Russell Nelson DeJong (1907-1990) has been associated with the University of Michigan since he enrolled as an undergraduate in 1925. He then also attended medical school, postgraduate training, and worked at the university until he became Chairman of the Department of Neurology in $1950^{34}$. He was president of the American Board of Psychiatry and Neurology, and the American Neurological Association ${ }^{33}$. He was also editor of the Year Book of Neurology since 1969 and has served with numerous governmental, professional, and voluntary health agencies. Since the beginning, and for 26 years thereafter, DeJong was editor of the Neurology, where he heavily influenced neurology in the U.S.A. ${ }^{34,36}$.

In 1950 he published his massive 1,079 pages "The Neurologic Examination"35 (Figure 9). The book divided in 10 parts, is based on lectures on the NE given to students in the University of Michigan Medical School. Already on the first page the reader comes across a famous quote from
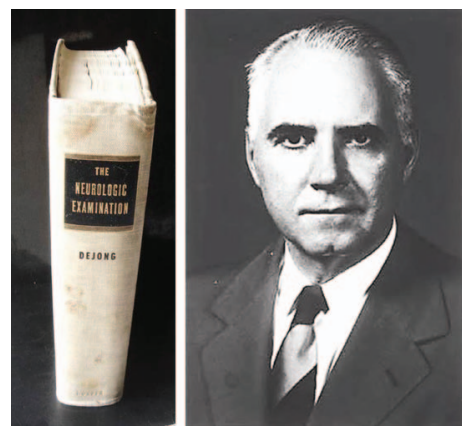

THE

NEUROLOGIC EXAMINATION

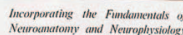
BY RUSSELL N. DEJONG, M.D. $=-1=-10+1$

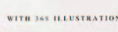
(1)

Figure 9. Russel N. DeJong and his first edition book (1950). 


\begin{tabular}{lcc}
\hline Title & Author & $1^{\text {th }}$ Edition \\
\hline A treatise on the nervous diseases* & John Cooke (1756-1838) \\
The nervous system of the human body* & Charles Bell (1774-1842) \\
Lectures on the nervous system and its diseases* & Marshal Hall (1790-1857) \\
Teaching book of nervous diseases of man* & Moritz Romberg (1795-1873) \\
Treatise on diseases of the nervous system & William Hammond (1826-1900) \\
A manual of diseases of the nervous system & William Gowers (1845-1915) \\
The nervous system and its diseases, a practical treatise on & Charles Mills (1845-1931) \\
neurology for the use of physician and students & Aloysio de Castro (1881-1959) \\
Tractado de semiotica nervosa & Monrad-Krohn (1884-1964) \\
Clinical examination of the nervous system & Derek Denny-Brown (1901-1980) \\
Handbook of neurological examination and case recording & Robert Wartenberg (1887-1956) \\
The examination of reflex a simplification & Gordon Holmes (1876-1965) \\
Introduction to clinical neurology & Russel N. DeJong (1907-1990) \\
The neurologic examination & Robert Wartenberg (1887-1956) \\
Diagnostic tests in neurology: a selection for office use &
\end{tabular}

* Only mentioned in text.

William Osler; "To study the phenomena of disease without books is to sail an uncharted sea, while to study books without patients is not to go to sea at all." In the preface, DeJong himself emphasizes the importance of neuroanatomy and neurophysiology for an adequate understanding of diseases of the nervous system.

Part one concerns the place and importance of neurologic evaluations in the general field of medicine, and contains a discussion of anamnesis and testing of the mental status. Part Five talks about a few reflexes indicative of damage in the basal ganglia, which are not currently surveyed. Part Ten is on examination of the spinal fluid. The book has an extensive reference list, and unlike prior NE books, contains a detailed chapter with 27 pages on the exam of patients with either hysteria or malingering. In 1992 this textbook was renamed "Dejong's The Neurologic Examination"33. This is certainly the most read neurological examination book in the Western world. The most recent edition, the seventh, was revised by William W. Campbell and published in $2013^{37}$.

In conclusion, it is worth questioning what these unforgettable authors possessed in common, besides, of course, a passion for neurology and a delicate, precise, and detailed fine NE. First, all have sought the opportunity of a great education, lived and followed masterful examples of good and outstanding medical scientists. As their professors, they were excellent and careful observers. Second, they persist on the path of belief in the purest science, always seeking the truth despite numerous vicissitudes such as political persecution and wars. The authors mentioned herein have made history and provide us with some of the most relevant contributions to the neurologic examination.

Many other authors such as Bordas, Austregesilo, Mumenthaler, Gardner and Lassek wrote magnificent books dealing with neurophysiology ${ }^{38}$, clinical neurology ${ }^{38,39,40,41}$, and specific neurological aspects ${ }^{40,42}$, but since their main focuses were not the systematization of the neurological examination they were not included in the present review. For the same reason, later authors that contributed to this field but did not pioneer the establishment of a neurological examination were also excluded.

\section{Acknowledgement}

The authors are in debt with Péricles Maranhão Neto for his technical assistance.

\section{References}

1. Goetz CG. French neurology and the work of Jean-Martin Charcot. In: 63rd AAN Annual Meeting; 2011 Apr 9-16; Hawaii, USA. Minneapolis: American Academy of Neurology; 2011. Course 6PC-003 CDROM-AAN 2011.

2. Fine EJ, Darkhabani Z. History of the development of the neurological examination. In: Finger S, Boller F, Tyler KL, editors. History of neurology. New York: Elsevier; 2010. p. 213-23. (Handbook of clinical neurology, vol. 95).

3. Goetz GC, Bounduelle M, Gelfand T. Charcot: constructing neurology. New York: Oxford University Press; 1995.
4. Eric J, Pappert EJ, Goetz CG. Early American neurologic textbooks. Neurology. 1995:45(6);1228-32. http://dx.doi.org/10.1212/ WNL.45.6.1228

5. Rose FC. Three early nineteenth century British neurological texts. In: Cliford Rose, editor. A short history of neurology: the British contribution 1660-1910. Great Britain: Butterworth-Heinemann; 1999. p. 117-31.

6. Romberg $\mathrm{MH}$. A manual of the nervous diseases of man. London: Sydenham Society; 1853 [cited 2013 May 12]. Vol. 1. Available from: https://archive.org/details/manualofnervousd01rombuoft 
Reynolds Historical Library. Hammond, William Alexander (18281900). [Cited 2013 May 11]. Available from: http://www.uab.edu/ reynolds/cwfigs/hammond

8. Hammond WA. A treatise on diseases of the nervous system. 6th ed. New York: D. Appleton; 1876 [cited 2013 Nov 11]. Available at: https://archive.org/details/atreatiseondise02hammgoog

9. Fine EJ. History of neurology: the origins of the neurological examination. In: 64th AAN Annual Meeting; 2012 April 21-29; New Orleans, USA. Minneapolis: American Academy of Neurology; 2012. Course 4PC-002. April 23, 2012

10. Tyler KL, Tyler HR. Sir William Richard Gowers (1845-1915): exhumation and decoding of his shorthand publication. In: Cliford R, editor. A short history of neurology: the British contribution 16601910. Great Britain: Butterworth-Heinemann; 1999. p. 208-21.

11. Tyler KL, McHenry LC Jr. Fragments of neurologic history: pseudohypertrophic muscular dystrophy and Gowers' sign. Neurology. 1983;33(1):88-9. http://dx.doi.org/10.1212/WNL.33.1.88

12. Gowers WR. A manual of diseases of the nervous system. Philadelphia: P. Blakiston; 1888.

13. Eadie MJ, Scott AEM, Lees AJ, Woodward M. William Gowers: the never completed third edition of the 'Bible of Neurology'. Brain. 2012;135(10):3178-88. http://dx.doi.org/10.1093/brain/aws181

14. Mills CK. The nervous system and its diseases: a practical treatise on neurology for the use of physicians and students. Philadelphia: J. B. Lippincott; 1898.

15. Pereira Júnior JJ. Vida e obra do Professor Aloysio de Castro. Acta Méd Chirurg Bras. 1979;5(4):40-2.

16. Castro A. Das desordens da marcha e seu valor clínico (Tese). Rio de Janeiro: Laemmert; 1904.

17. Pontes JPL. Aloysio de Castro. F Méd (BR). 1981;83(3):271-7.

18. Nava P. A medicina de Os Lusíadas. Cotia: Ateliê; 2004. Capítulo 3, Aloysio de Castro, o gentil-homem da medicina brasileira; p. 73-101.

19. Castro A. Tractado de semiotica nervosa. Rio de Janeiro: F. Briquiet; 1914.

20. Castro A. Semiotica nervosa. 2nd ed. Rio de Janeiro: F. Briguiet; 1935.

21. Boes CJ. Examination of reflex and textbooks devoted to the neurologic examination. In: 64th AAN Annual Meeting; 2012 April 21-28; New Orleans, USA. Minneapolis: American Academy of Neurology; 2012. Course 4PC-002. April 23, 2012.

22. Krohn M, Refsum S. Exploración clínica del sistema nervioso. Barcelona: Labor; 1967.
23. Pearce JMS. Sir Gordon Holmes (1876-1965). J Neurol Neurosurg Psychiatry. 2004;75(10):1502-3. http://dx.doi.org/10.1136/jnnp.2003. 016170

24. McDonald I. Gordon Holmes lecture: Gordon Holmes and the neurological heritage. Brain. 2007;130(Pt 1):288-98.

25. Gilman SD. Denny-Brown 1901-1981. Neurology. 1982;32(1):1-6.

26. Denny-Brown D. Handbook of neurological examination and case recording. Cambridge: Massachusetts Harvard University Press; 1952.

27. Denny-Brown D, Kirk EJ, Yanagisawa N. The tract of Lissauer in relation to sensory transmission in the dorsal horn of spinal cord in the macaque monkey. J Comp Neurol. 1973;151(2):175-200. http://dx. doi.org/10.1002/cne.901510206

28. Wartenberg R. The examination of reflexes a simplification. Chicago: Year Book; 1946.

29. Wartenberg R. Diagnostic tests in neurology a selection for office use. Chicago: Year Book; 1954.

30. Wartenberg R. Pendulousness of the legs as a diagnostic test. Neurology. 1951;1(1):18-24. http://dx.doi.org/10.1212/WNL.1.1.18

31. Finger S. Origins of neuroscience. New York: Oxford University Press; 1994.

32. Holmes G. Introduction to clinical neurology. 3rd ed. Great Britain: Longman Group; 1971.

33. Baker AB. A tribute to Russel DeJong, founding Editor-in-Chief. Neurology. 1977;27(1):1-2. http://dx.doi.org/10.1212/WNL.27.1.1

34. Rowland LP. A statement from the new Editor-in-Chief [editorial]. Neurology. 1977;27(1):2. http://dx.doi.org/10.1212/WNL.27.1.2

35. DeJong RN. The neurologic examination. New York: Harper \& Brothers; 1950.

36. B AB. The neurologic examination [book reviews]. Neurology. 1951;1(1):97.

37. Campbell WW. DeJong's The neurologic examination. 7th ed. Philadelphia: Lippincott Williams \& Wilkins; 2013.

38. Bordas LB. Neurologia fundamental. Barcelona: Kalimax; 1973.

39. Austregesilo A. Clínica neurológica. Rio de Janeiro: Francisco Alves; 1917.

40. Mumenthaler M, Schliack H. Patologia de los nervios periféricos: diagnóstico y tratamiento. Barcelona: Toray; 1976.

41. Gardner E. Fundamentals of neurology. Philadelphia: WB Saunders; 1947.

42. Lassek AM. The pyramidal tract: its status in medicine. Springfield: Charles Thomas; 1954. 